\title{
Microwave-assisted synthesis and antioxidant properties of hydrazinyl thiazolyl coumarin derivatives
}

\author{
Hasnah Osman ${ }^{1 *}$, Afsheen Arshad ${ }^{1}$, Chan Kit Lam ${ }^{2}$ and Mark C Bagley ${ }^{3^{*}}$
}

\begin{abstract}
Background: Coumarin derivatives exhibit a wide range of biological properties including promising antioxidant activity. Furthermore, microwave-assisted organic synthesis has delivered rapid routes to $\mathrm{N}$ - and $\mathrm{O}$-containing heterocycles, including coumarins and thiazoles. Combining these features, the use of microwave-assisted processes will provide rapid access to a targeted coumarin library bearing a hydrazino pharmacophore for evaluation of antioxidant properties

Results: Microwave irradiation promoted 3 of the 4 steps in a rapid, convergent synthesis of a small library of hydrazinyl thiazolyl coumarin derivatives, all of which exhibited significant antioxidant activity comparable to that of the natural antioxidant quercetin, as established by DPPH and ABTS radical assays

Conclusions: Microwave dielectric heating provides a rapid and expedient route to a series of hydrazinyl thiazolyl coumarins to investigate their radical scavenging properties. Given their favourable properties, in comparison with known antioxidants, these coumarin derivatives are promising leads for further development and optimization.
\end{abstract}

Keywords: Coumarins, Thiazoles, Antioxidant activity, Microwave synthesis

\section{Background}

The synthesis and biological activities of coumarin derivatives occupy an important position in heterocyclic chemistry as well as in medicinal chemistry. The compounds containing this heterocyclic motif are widely found as additives in food, in cosmetic products, as pharmaceutical agents [1] and as luminescent materials [2]. They have pronounced medicinal value as anticoagulants [3], free radical scavengers [4,5], and as lipoxygenase [6] and cyclooxygenase inhibitors [7]. Moreover, many coumarins exhibit high antibacterial [8], antifungal [9] and cytotoxic activities [10]. The incorporation of a 3-thiazolyl substituent can further enhance the activity of this pharmacophore: thiazolyl coumarins have been reported to exhibit anticonvulsant [11], anticancer, antimicrobial [12], analgesic and anti-inflammatory properties [13] and display

\footnotetext{
*Correspondence: ohasnah@usm.my; M.C.Bagley@sussex.ac.uk

${ }^{1}$ School of Chemical Sciences, Universiti Sains Malaysia, 11800, Penang, Malaysia

${ }^{3}$ Department of Chemistry, School of Life Sciences, University of Sussex, Brighton BN1 9QJ, UK

Full list of author information is available at the end of the article
}

good activity against Mycobacterium tuberculosis [14] and Helicobactor pylori [15]. The pathophysiology of many of the above-mentioned diseases, and others, has been linked with oxidative stress, produced in our body as a result of various oxidation processes essential for life. Although the importance of antioxidants to prevent the progression of age-related diseases, or interfere in the ageing process itself, could be contested [16,17], their role in enzymatic and non-enzymatic defense mechanisms in both the lipid and aqueous phase is well established [18]. Given that coumarin and its derivatives are well-known as antioxidants [19], we set out to access a series of thiazolyl coumarin derivatives, rapidly and in a convergent manner, to explore their antioxidant properties. Previously we have reported the synthesis and crystalline structure of various thiazolyl coumarin derivatives prepared by conventional methods, including the synthesis of a series of hydrazinyl thiazolyl coumarins [20-24]. Given the versatility and capability of microwave-assisted synthesis for rapid delivery of compounds of biological interest [25-28], our previous success in the use of microwave irradiation for the rapid synthesis of thiazoles of biological interest [29,30], and the
(C) Chemistry Central

(c) 2012 Osman et al; licensee BioMed Central Ltd. This article is published under license to BioMed Central Ltd. This is an Open Access article distributed under the terms of the Creative Commons Attribution License (http://creativecommons.org/licenses/by/ 2.0), which permits unrestricted use, distribution, and reproduction in any medium, provided the original work is properly cited. 
previous application of this technology in the synthesis of coumarins, both on small and large scale [31-34], as well as thiazolyl coumarin Schiff bases [35], we set out to investigate a rapid microwave-assisted synthesis of a hydrazinyl thiazolyl coumarin library for evaluation of in vitro antioxidant activity by DPPH radical and ABTS radical cation assays, using the natural antioxidant quercetin and a synthetic antioxidant (butylatedhydroxytoluene) as reference standards.

\section{Results and discussion}

3-(Bromoacetyl)coumarin (4), a key precursor of Hantzsch thiazole synthesis for the hydrazinyl thiazolyl coumarin library, was prepared by a two-step sequence (Scheme 1). Firstly Knoevenagel condensation, with spontaneous $\alpha$ pyrone 3 formation, was investigated by heterocyclocondensation of salicylaldehyde (1) and ethyl acetoacetate (2) under microwave irradiation using a range of conditions (Table 1). It has been reported that the use of microwave heating is beneficial for 3-acetylcoumarin synthesis, allowing for low catalyst loadings and short reaction times to limit the generation of unwanted side products [33,34]. Although solvent-free conditions have been used for $\alpha$ pyrone 3 formation under microwave irradiation [31,32] and conventional heating [36], in the presence of a catalytic amount of piperidine or L-proline, these give rise to widely varying reaction times, operating temperatures and thus chemical yields [31]. In our hands (entry 1), the solvent-free process resulted in a rapid rise of pressure and so was discarded in favour of the more reliable Leadbeater method, carried out in ethanol solvent, which has been reported to proceed in reasonable yield (67-81\%) on multigram scale in sealed vessel microwave apparatus [33] and more recently in a large scale batch reactor [34]. In our modified procedure, on $18 \mathrm{mmol}$ scale, with a small excess of carbonyl compound 2 (1.3 equiv), the use of piperidine base (entries 6-8) seemed superior to the Lproline catalyst (entries 2-5) giving 3-acetylcoumarin (3) in $99 \%$ isolated yield in a reaction time of only $5 \mathrm{~min}$ (entry 8 ) following purification by recrystallization.

With a rapid and highly efficient route to acetylcoumarin 3 established, the first of the building blocks for Hantzsch thiazole synthesis, bromoacetylcoumarin 4, was prepared in $68 \%$ yield by the electrophilic bromination of acetylcoumarin 3, in $\mathrm{CHCl}_{3}$, according to the method of
Table 1 Conditions for the microwave-assisted synthesis of 3-acetylcoumarin (3)

\begin{tabular}{lllc}
\hline Entry & Base & Reagents \& conditions $^{\dagger}$ & Yield\% $^{\dagger}$ \\
\hline 1 & Piperidine & Solvent-free, $50^{\circ} \mathrm{C}, 5 \mathrm{~min}$ & $-{ }^{a}$ \\
2 & L-Proline & $\mathrm{EtOH}, 50^{\circ} \mathrm{C}, 5 \mathrm{~min}$ & 54 \\
3 & L-Proline & $\mathrm{EtOH}, 50^{\circ} \mathrm{C}, 10 \mathrm{~min}$ & 59 \\
4 & L-Proline & $\mathrm{EtOH}, 120^{\circ} \mathrm{C}, 1 \mathrm{~min}$ & 72 \\
5 & L-Proline & $\mathrm{EtOH}, 120^{\circ} \mathrm{C}, 2 \mathrm{~min}$ & 93 \\
6 & Piperidine & $\mathrm{EtOH}, 120^{\circ} \mathrm{C}, 1 \mathrm{~min}$ & 74 \\
7 & Piperidine & $\mathrm{EtOH}, 120^{\circ} \mathrm{C}, 10 \mathrm{~min}$ & 98 \\
8 & Piperidine & $\mathrm{EtOH}, 50^{\circ} \mathrm{C}(20 \mathrm{~W}), 5$ min & 99 \\
\hline
\end{tabular}

${ }^{\dagger}$ All reactions were carried out using $5 \mathrm{~mol} \%$ of base under microwave dielectric heating at the given temperature in a sealed tube using a CEM Discover single-mode microwave synthesizer by moderation of the initial magnetron power (20-150 W). Isolated yield after recrystallization (ethanol).

${ }^{a}$ Reaction was halted upon the rapid build-up of pressure.

Gursoy and Karali [14] (Scheme 1). Furthermore the second, thioamide, component was provided by the condensation of thiosemicarbazide $\mathbf{5}$ and one member of a subset of benzaldehydes $\mathbf{6}$ or naphthaldehydes $\mathbf{8}$ in a microwaveassisted condensation. Microwave irradiation of a methanolic solution of a range of these precursors at $120^{\circ} \mathrm{C}$ for $10 \mathrm{~min}$ (Scheme 2) gave thiosemicabazones 7 or $\mathbf{9}$, respectively, in excellent isolated yield (70-92\%) after purification by recrystallization (Table 2). The efficiency of the microwave-assisted procedure compared highly favourably, in terms of isolated yield and reaction time, with the condensation carried out using more traditional methods, at reflux in $\mathrm{MeOH}$ in the presence of $\mathrm{AcOH}$ for 1-4 h, using the same isolation and purification regime.

Given that microwave irradiation has been used before in the synthesis of thiazole derivatives of biological interest [29,30,37-39] and that, in particular, Hantzsch thiazole synthesis conducted in ethanol was successful in generating thiazoles in good yields for evaluation of antiproliferative activity [40], the Hantzsch synthesis of thiazolyl coumarins 10a-h from corresponding building blocks was investigated under related conditions (Scheme 3). Microwave irradiation of semicarbazone 7,9 and bromoketone 4 in ethanol at $60^{\circ} \mathrm{C}$ for $10 \mathrm{~min}$ (hold time) followed by treatment with ammonium hydroxide $(5 \%)$ gave coumarin derivatives $\mathbf{1 0 a}-\mathbf{h}$ in very good yield (71-80\%) (Table 3 ). In all cases, the isolated yield after purification by recrystallization was closely comparable with traditional

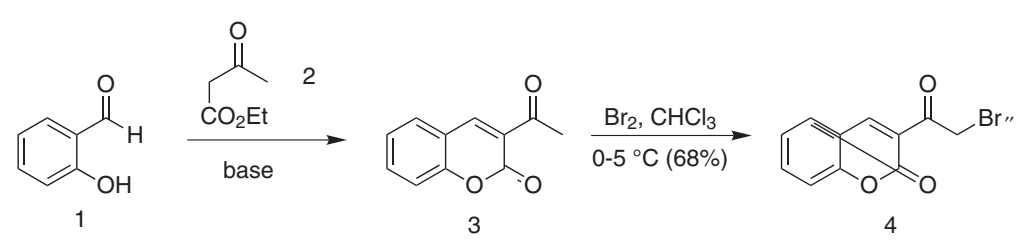

Scheme 1 Synthesis of 3-(bromoacetyl)coumarin (4) component for Hantzsch thiazole synthesis. 


$$
\text { (70-82\%) }
$$
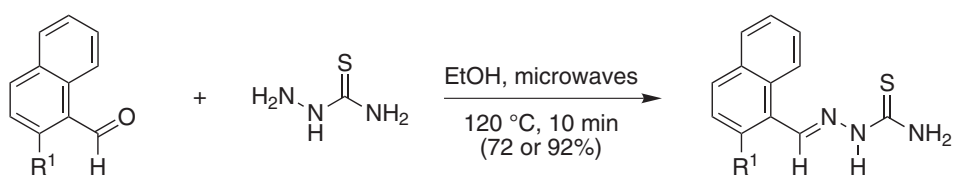

Scheme 2 Synthesis of the thiosemicarbazone (7 or 9) component for Hantzsch thiazole synthesis.

conductive heating methods (see Table 3). The identity and purity was confirmed by analysis of spectroscopic and mass spectrometric data and by comparing the melting point with literature values [20]. The use of microwave irradiation had facilitated and accelerated 3 out of the 4 steps in the convergent synthesis of thiazolyl coumarins 10a-h, including two heterocyclocondensations ( $\alpha$-pyrone formation and Hantzsch thiazole synthesis) and semicabazone formation, to provide an extremely rapid route to a focused library for examination of antioxidant properties.

Hydrazino-thiazole derivatives have been shown recently to possess radical scavenging ability and some simple structure-activity relationships have been described for a small library of compounds [41]. The antioxidant properties of this motif were evaluated quickly and efficiently using a 1,1-diphenyl-2-picrylhydrazyl (DPPH) radical scavenging

Table 2 Isolated yields for the microwave-assisted condensation of benzaldehydes 6 or naphthaldehydes 8 with thiosemicarbazide 5 and comparison with traditional methods

\begin{tabular}{lccccccc}
\hline Entry & Compound & $\mathbf{R}^{1}$ & $\mathbf{R}^{2}$ & $\mathbf{R}^{3}$ & $\mathbf{R}^{4}$ & $\begin{array}{c}\text { Yield\% under } \\
\text { microwave } \\
\text { irradiation }\end{array}$ & $\begin{array}{c}\text { Yield\% using } \\
\text { traditional } \\
\text { conditions }\end{array}$ \\
\hline 1 & 7a & $\mathrm{OH}$ & $\mathrm{H}$ & $\mathrm{H}$ & $\mathrm{H}$ & 70 & 69 \\
2 & 7b & $\mathrm{H}$ & $\mathrm{OH}$ & $\mathrm{H}$ & $\mathrm{H}$ & 82 & 66 \\
3 & 7c & $\mathrm{H}$ & $\mathrm{H}$ & $\mathrm{OH}$ & $\mathrm{H}$ & 71 & 71 \\
4 & 7d & $\mathrm{OH}$ & $\mathrm{H}$ & $\mathrm{OH}$ & $\mathrm{H}$ & $n / a$ & 76 \\
5 & 7e & $\mathrm{OH}$ & $\mathrm{H}$ & $\mathrm{H}$ & $\mathrm{Br}$ & 78 & 64 \\
6 & 7f & $\mathrm{OH}$ & $\mathrm{OMe}$ & $\mathrm{H}$ & $\mathrm{H}$ & 72 & 69 \\
7 & 9a & $\mathrm{H}$ & - & - & - & 92 & 67 \\
8 & 9b & $\mathrm{OH}$ & - & - & - & 72 & 62 \\
\hline
\end{tabular}

${ }^{\dagger}$ Isolated yield after microwave dielectric heating in $\mathrm{EtOH}$ at $120^{\circ} \mathrm{C}$ for $10 \mathrm{~min}$ (hold time) in a sealed tube using a CEM Discover single-mode microwave synthesizer by moderation of the initial magnetron power (20-150 W), followed by purification by recrystallization (EtOH). ${ }^{*}$ Isolated yield after reaction by traditional conductive heating at reflux in $\mathrm{MeOH}$ in the presence of $\mathrm{AcOH}$ for $1-4 \mathrm{~h}$ and purification by recrystallization ( $\mathrm{EtOH}$ or $\mathrm{EtOH}-\mathrm{CHCl}_{3}$ ) (see reference 20 for details). $n / a$ Experiment not investigated. model [42] in which the decrease in the strong absorption band at $v 517 \mathrm{~nm}$ due to the unpaired electron in DPPH decreased stoichiometrically on scavenging an electron or hydrogen atom. Using the DPPH free radical assay, according to a modification of our previously reported procedure [43], the radical scavenging activity of this new series of thiazolyl coumarins 10a-h was determined and expressed as $\mathrm{IC}_{50}$ values $[41,43]$, which is the concentration of tested compound required to scavenge $50 \%$ of the DPPH radical concentration $(0.11 \mathrm{mM}$ in this case on dilution). All of the DPPH assays were conducted in triplicate and both a synthetic antioxidant, 2,6-di-tert-butyl-4-methylphenol (BHT), and the natural antioxidant quercetin were used as reference standards. The results from the DPPH radical scavenging assay were validated by $2,2^{\prime}$-azinobis (3-ethylbenzothiazoline-6-sulfonate) (ABTS) assay [42,44], which established $\mathrm{IC}_{50}$ values for each tested compound to trap the $\mathrm{ABTS}^{+}$radical. For consistency, $\mathrm{IC}_{50}$ values in ABTS assay were established in triplicate and compared with quercetin, again, and Trolox, which is a common reference antioxidant for interaction with $\mathrm{ABTS}^{+}$ [42,44-46]. As expected, DPPH radical assay indicated that radical scavenging activity was dose dependent and increased with the concentration of the tested compound (Figure 1). The $\mathrm{IC}_{50}$ values of thiazolyl coumarins $10 \mathbf{a}-\mathbf{h}$ in the DPPH assay were found to be in the range 16$85 \mu \mathrm{M}$ (Table 4), displaying excellent antioxidant activity above and beyond that of BHT and comparable to that of quercetin (Figure 2). It was worthy to note that compounds 10a, 10c, 10d, 10e, 10f and $10 \mathrm{~h}$ exhibited very high activity against the DPPH radical (at a concentration of $0.11 \mathrm{mM}$ ) with $\mathrm{IC}_{50}$ values in the order of $16-30 \mu \mathrm{M}$. The activity of this thiazolyl coumarin library compared closely with other known hydrazino-thiazoles $\left(\mathrm{IC}_{50} 15-\right.$ $60 \mu \mathrm{M}$ at a DPPH radical concentration of $0.1 \mathrm{mM}$ ) [41] implying that the coumarin and phenolic functions had not adversely affected antioxidant activity. The activity of these compounds was attributed for the most part to the hydrazinothiazole functionality but clearly was modulated 


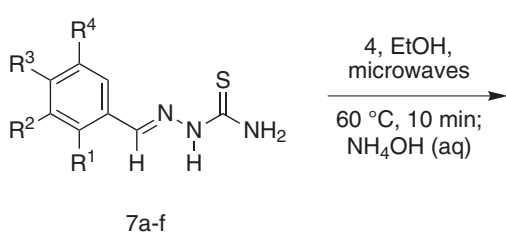

$7 a-f$

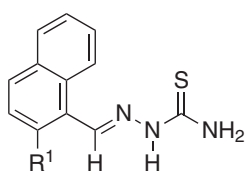

$9 a, b$

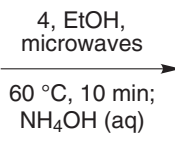

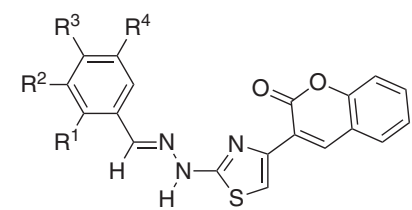

10a-f $R^{1}, R^{2}, R^{3}, R^{4}$ :

a $\mathrm{OH}, \mathrm{H}, \mathrm{H}, \mathrm{H}(74 \%)$; b H, OH, $\mathrm{H}, \mathrm{H}(80 \%)$;

c H, H, OH, H (71\%); d OH, H, OH, H [ref. 20];

e $\mathrm{OH}, \mathrm{H}, \mathrm{H}, \mathrm{Br}(72 \%)$; f OH, OMe, $\mathrm{H}, \mathrm{H}(72 \%)$.

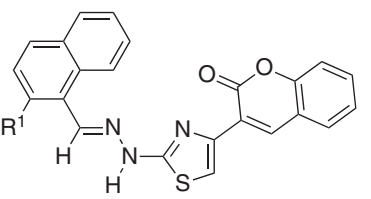

$\operatorname{log~H}(71 \%) ; 10 \mathrm{~h} \mathrm{OH}(79 \%)$.

Scheme 3 Hantzsch synthesis of thiazolyl coumarins 10a-h.

and enhanced by the incorporation of other unique groups. The presence of the hydrazino N-H group (Scheme 4) and the phenolic hydroxyl were viewed as important structural features, both having the ability for hydrogen atom transfer (HAT) to the DPPH free radical to give a resonance stabilized radical 11a-f. The mesomeric stabilization of this radical, in particular through the addition of electron donating aromatic units could contribute to radical scavenging ability, with notable improvements observed for 2-hydroxy 10a and 4-hydroxyphenyl 10c analogues over the 3-hydroxy precursor 10b (Table 4, entry 2). Alternatively sequential proton loss electron transfer (SPLET) could compete with HAT (Scheme 4c)

Table 3 Comparison of isolated yields for microwave-assisted and conventional Hantzsch synthesis of thiazolyl coumarins 10

\begin{tabular}{lccc}
\hline Entry & Compound & $\begin{array}{c}\text { Yield\% under } \\
\text { microwave irradiation }^{\dagger}\end{array}$ & $\begin{array}{c}\text { Yield\% using } \\
\text { traditional conditions }^{*}\end{array}$ \\
\hline 1 & 10a & 74 & 70 \\
2 & 10b & 80 & 72 \\
3 & 10c & 71 & 80 \\
4 & 10d & $n / a$ & 72 \\
5 & 10e & 72 & 78 \\
6 & 10f & 72 & 70 \\
7 & 10g & 71 & 70 \\
8 & 10h & 79 & 75 \\
\hline
\end{tabular}

${ }^{\dagger}$ Isolated yield after microwave dielectric heating in $\mathrm{EtOH}$ at $60^{\circ} \mathrm{C}$ for $10 \mathrm{~min}$ (hold time) in a sealed tube using a CEM Discover single-mode microwave synthesizer by moderation of the initial magnetron power (30 W), followed by treatment with aqueous base and purification by recrystallization.

* Isolated yield after reaction by traditional conductive heating at reflux in EtOH-CHCl ${ }_{3}$ for $1-4 \mathrm{~h}$, basification with $\mathrm{NH}_{3}(\mathrm{aq})$ and purification by recrystallization (see reference 20 for details). $n / a$ Experiment not investigated. for phenolic scavengers $(\mathrm{ArOH})$ as has been described for curcumin [42]. In this latter case, synergistic contributions to the activity of phenolic and hydrazino scavengers could not be ruled out but these features were not explored further. The presence of hydroxyl groups in compounds 10a$10 \mathrm{f}$ and $\mathbf{1 0 h}$ appeared to contribute to the antioxidant activity of these compounds and when absent resulted in a dramatic loss of radical scavenging ability (Table 4, compare lower activity of $\mathbf{1 0 g}$ in entry 7 with entry 8 ), suggesting the involvement of a SPLET mechanism. The reaction of the DPPH radical with scavengers (Scheme 4a) in general suggests a 1:1 stoichiometry of reaction at high scavenger concentration. When the concentration of the tested compounds is significantly lower than the DPPH radical, as could be the case for compounds with potent $\mathrm{IC}_{50}$ values, the remaining DPPH radical may combine with the hydrazinyl thiazolyl radical 11a-f (Scheme $4 \mathrm{~b}$ ) and thus, the stoichiometry of the reaction could appear higher than 1:1 [41]. Finally, on review it was bromophenyl analogue 10e that exhibited the highest activity in the DPPH assay (Table 4, entry 5) even exceeding the activity of the natural antioxidant quercetin (entry 10).

The findings from the DPPH assays correlated well with $\mathrm{IC}_{50}$ values derived in ABTS experiments. The ABTS radical was generated by treatment with the strong oxidizing agent $\mathrm{K}_{2} \mathrm{~S}_{2} \mathrm{O}_{8}$ and then reduced by the addition of the antioxidant; this was observed by the suppression of the characteristic long wave absorption of $\mathrm{ABTS}^{+}$. For the most part, the mean $\mathrm{IC}_{50}$ values were of very similar magnitude with minimal differences between the ABTS and DPPH values (Table 4), an observation that has been made before in measuring antioxidant activities of sorghum products [47]. Thus no matter which assay was used, the compounds exhibited the 


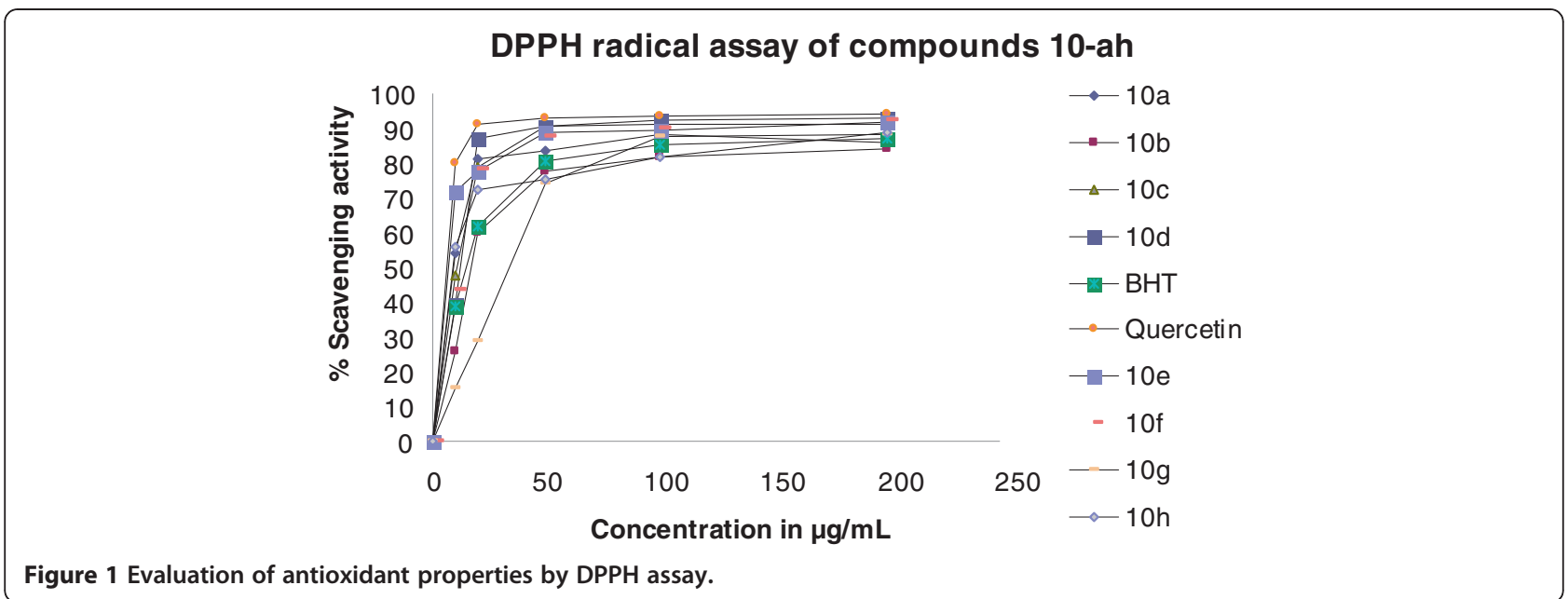

same activity trends and SAR (Figure 2), validating the reliability of both techniques. However, it was noted that there appeared to be greater consistency with the DPPH data and greater variability in the ABTS $\mathrm{IC}_{50}$ values according to the observed standard deviations.

\section{Conclusions}

The synthesis and antioxidant activity of hydrazinyl thiazolyl coumarin derivatives have been reported. Microwave irradiation promoted 3 out of the 4 steps to establish an extremely rapid, convergent and highly efficient route to the target library. All of the compounds were purified by recrystallization and obtained in good isolated yields, with spectroscopic and

\begin{tabular}{|c|c|c|c|c|c|c|c|}
\hline Entry & Compound & $\mathbf{R}^{1}$ & $R^{2}$ & $R^{3}$ & $\mathrm{R}^{4}$ & $\begin{array}{l}\text { DPPH assay } \\
\mathrm{IC}_{50} / \mu \mathrm{M}^{\dagger}\end{array}$ & $\begin{array}{l}\text { ABTS assay } \\
\mathrm{IC}_{50} / \mu \mathrm{M}^{*}\end{array}$ \\
\hline 1 & $10 a$ & $\mathrm{OH}$ & $\mathrm{H}$ & $\mathrm{H}$ & $\mathrm{H}$ & $26 \pm 0.96$ & $32 \pm 3.06$ \\
\hline 2 & $10 \mathrm{~b}$ & $\mathrm{H}$ & $\mathrm{OH}$ & $\mathrm{H}$ & $\mathrm{H}$ & $47 \pm 1.24$ & $53 \pm 2.74$ \\
\hline 3 & $10 c$ & $\mathrm{H}$ & $\mathrm{H}$ & $\mathrm{OH}$ & $\mathrm{H}$ & $28 \pm 0.62$ & $41 \pm 3.95$ \\
\hline 4 & $10 d$ & $\mathrm{OH}$ & $\mathrm{H}$ & $\mathrm{OH}$ & $\mathrm{H}$ & $24 \pm 0.67$ & $29 \pm 1.88$ \\
\hline 5 & $10 e$ & $\mathrm{OH}$ & $\mathrm{H}$ & $\mathrm{H}$ & $\mathrm{Br}$ & $16 \pm 0.82$ & $19 \pm 2.76$ \\
\hline 6 & $10 f$ & $\mathrm{OH}$ & OMe & $\mathrm{H}$ & $\mathrm{H}$ & $30 \pm 0.78$ & $36 \pm 3.18$ \\
\hline 7 & $10 \mathrm{~g}$ & $\mathrm{H}$ & - & - & - & $85 \pm 0.66$ & $78 \pm 5.64$ \\
\hline 8 & $10 \mathrm{~h}$ & $\mathrm{OH}$ & - & - & - & $22 \pm 1.75$ & $32 \pm 3.42$ \\
\hline 9 & BHT & - & - & - & - & $71 \pm 0.82$ & - \\
\hline 10 & quercetin & - & - & - & - & $18 \pm 0.99$ & $20 \pm 2.19$ \\
\hline 11 & Trolox & - & - & - & - & - & $112 \pm 4.29$ \\
\hline
\end{tabular}

${ }^{\dagger}$ Required concentration of the tested compound to scavenge $50 \%$ of the DPPH radical present at a concentration of $0.1 \mathrm{mM}$; average from 3 assays. * Required concentration of the tested compound to scavenge $50 \%$ of the ABTS radical present at a concentration of $0.12 \mathrm{mM}$; average from 3 assays. physical data that fully supported the proposed structures. DPPH and ABTS assays indicated that almost all of the synthesized hydrazinyl thiazolyl coumarin derivatives $(10 a, 10 c, 10 d, 10 e, 10$ and $10 \mathrm{~h})$ had significant radical scavenging activity that was comparable or better than the known antioxidants, quercetin, BHT and Trolox. The thiazole, hydrazino, and phenolic moieties are the likely structural components contributing to free radical scavenging activity. However, the facile incorporation of the coumarin motif offers an opportunity to further optimize radical scavenging activity in the future for hitto-lead development of new and improved synthetic antioxidants.

\section{Experimental}

Preparation of 3-acetyl-2H-chromen-2-one (3) by knoevenagel condensation

Piperidine $(0.1 \mathrm{~mL})$ was added dropwise to a mixture of salicylaldehyde $(2.0 \mathrm{~mL}, 18 \mathrm{mmol})$ and ethyl acetoacetate $(3.0 \mathrm{~mL}, 24 \mathrm{mmol})$ in EtOH $(1.0 \mathrm{~mL})$ The reaction mixture was stirred under microwave irradiation for $5 \mathrm{~min}$ (hold time) at $50^{\circ} \mathrm{C}$ (initial power $20 \mathrm{~W}$ ) and then was cooled in a stream of compressed air, resulting in a yellow solid. Purification by recrystallization $(\mathrm{EtOH})$ gave the title compound 3 (3.3 g, 99\%) as fine yellow needles, mp $118-119^{\circ} \mathrm{C}$ (Lit. mp $119-121^{\circ} \mathrm{C}$ [48]); IR (KBr) $v_{\max }$ 2930 (C-H aliphatic), $1742(\mathrm{C}=\mathrm{O}), 1677(\mathrm{O}-\mathrm{C}=\mathrm{O}) ;{ }^{1} \mathrm{H}$ NMR $\left(500 \mathrm{MHz}, \mathrm{DMSO}-d_{6}\right) \delta 8.58(1 \mathrm{H}, \mathrm{s}), 7.89(1 \mathrm{H}$, dd, $J=7.6,1.6 \mathrm{~Hz}), 7.70(1 \mathrm{H}$, ddd, $J=8.1,7.6,1.6 \mathrm{~Hz})$, $7.40(1 \mathrm{H}, \mathrm{d}, J=8.1 \mathrm{~Hz}), 7.38(1 \mathrm{H}, \mathrm{td}, J=7.6,1 \mathrm{~Hz}), 2.55$ $(3 \mathrm{H}, \mathrm{s})$.

Alternatively L-proline $(0.18 \mathrm{~g}, 16 \mathrm{mmol})$ was added to a mixture of salicylaldehyde $(2.0 \mathrm{~mL}, 18 \mathrm{mmol})$ and ethyl acetoacetate $(3.0 \mathrm{~mL}, 24 \mathrm{mmol})$ in $\mathrm{EtOH}(1.0 \mathrm{~mL})$. The reaction mixture was stirred under microwave radiation for $1-10 \mathrm{~min}$ (hold time) at 50 or $120^{\circ} \mathrm{C}$, resulting in the 


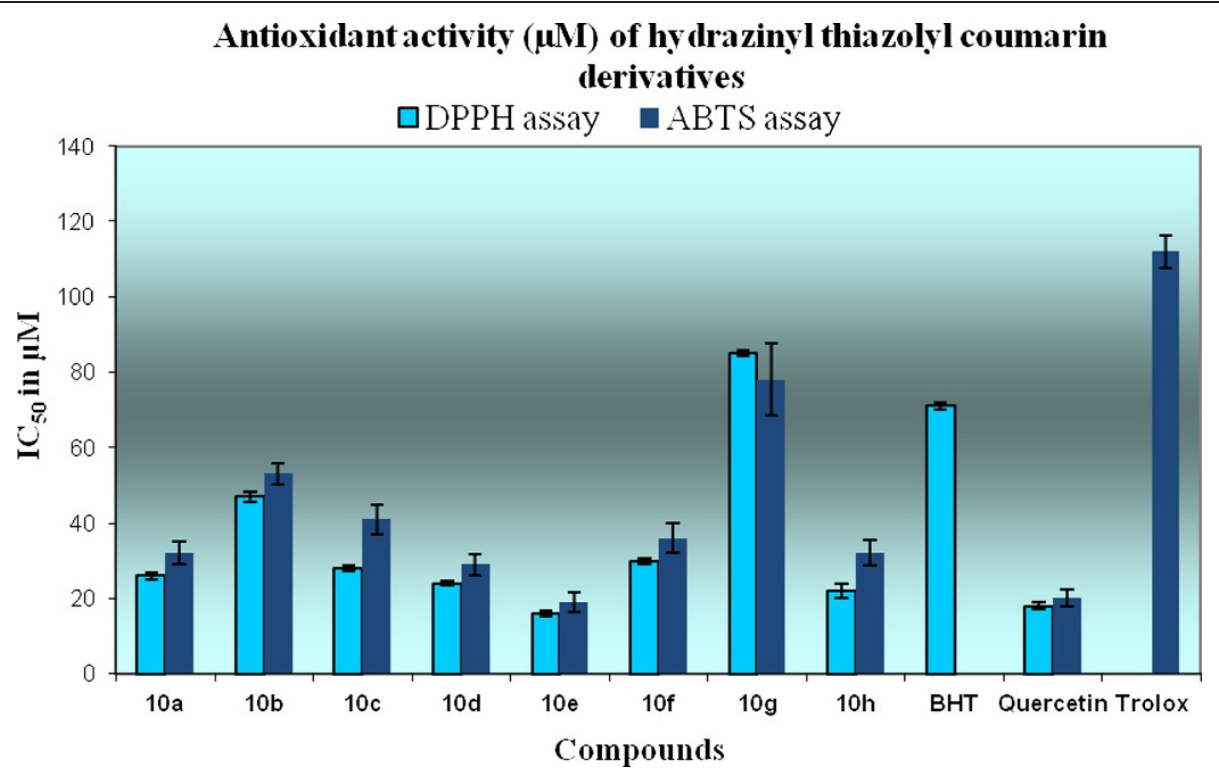

Figure 2 Comparing antioxidant activities using DPPH and ABTS assays.

formation of a yellow solid. Purification by recrystallization $(\mathrm{EtOH})$ gave the title compound 3 (2.8 g, 93\%) (Table 2, entry 4) as fine yellow needles, mp 117$118^{\circ} \mathrm{C}$ (Lit. mp $119-121^{\circ} \mathrm{C}$ [48]) with identical spectroscopic properties.

\section{Bromination of acetylcoumarins}

3-Acetyl-2H-chromen-2-one (3) (20 g, $0.11 \mathrm{~mol})$, obtained from the combined product of a series of parallel experiments, was dissolved in alcohol-free $\mathrm{CHCl}_{3}(20 \mathrm{~mL})$ and a solution of $\mathrm{Br}_{2}(5.45 \mathrm{~mL}, 0.11 \mathrm{~mol})$ in $\mathrm{CHCl}_{3}(20 \mathrm{~mL})$ was

(a) Possible radical scavenging mechanism at high scavenger concentration

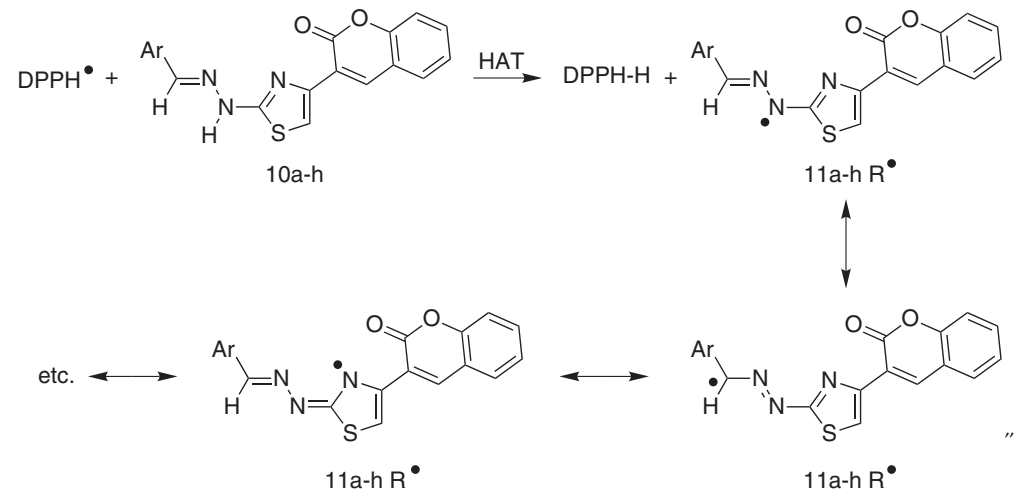

(b) Radical scavenging at low scavenger concentration (>1:1 stoichiometry)

$\mathrm{DPPH}^{\bullet}+\mathrm{R}^{\bullet} \rightleftharpoons \mathrm{DPPH}-\mathrm{R}$

(c) Alternative radical scavenging mechanisms for phenolic ( $\mathrm{ArOH})$ scavengers

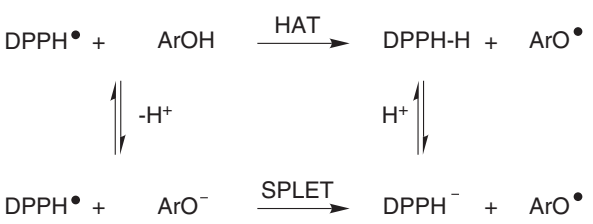

Scheme 4 DPPH radical scavenging reactions of hydrazinyl thiazolyl coumarins 10a-h and phenolic (ArOH) scavengers [41,42]. 
added dropwise from a dropping funnel with constant stirring at $0-5^{\circ} \mathrm{C}$. After $3 \mathrm{~h}$, a dark yellow solid separated. The reaction mixture was heated for $15 \mathrm{~min}$ at reflux, cooled and $\mathrm{CHCl}_{3}$ was removed using a rotary evaporator. Purification by recrystallization (glacial $\mathrm{AcOH}$ ) gave 3-bromoacetylcoumarin 4 (19 g, 68\%) as off-white needles, $\mathrm{mp} 162-165^{\circ} \mathrm{C}$ (Lit. mp 160$163^{\circ} \mathrm{C}$ [11]); IR (KBr) $v_{\max } 2930$ (C-H aliphatic), $1731(\mathrm{C}=\mathrm{O}), 1686(\mathrm{O}-\mathrm{C}=\mathrm{O}) ;{ }^{1} \mathrm{H}$ NMR $(400 \mathrm{MHz}$, $\left.\mathrm{CDCl}_{3}\right) \delta 8.66(1 \mathrm{H}, \mathrm{s}), 7.69-7.75(2 \mathrm{H}, \mathrm{m}), 7.39-7.44$ $(2 \mathrm{H}, \mathrm{m}), 4.79(2 \mathrm{H}, \mathrm{s})$.

\section{General procedure for the preparation of} thiosemicarbazones $7 \mathrm{a}-\mathrm{f}$ or $9 \mathrm{a}, \mathrm{b}$ from aldehydes $6 \mathrm{a}-\mathrm{f}$ or $8 a, b$, respectively

Thiosemicarbazide (5) (0.46 g, $5.00 \mathrm{mmol})$ was added slowly to a stirred solution of salicylaldehyde $(0.11 \mathrm{~mL}$, $5.00 \mathrm{mmol})$ in hot absolute $\mathrm{EtOH}(5 \mathrm{~mL})$. The resulting solution was heated at $120^{\circ} \mathrm{C}$ for 10 min (hold time) under microwave irradiation. The mixture was cooled in a stream of compressed air, then allowed to cool further in an ice bath for $30 \mathrm{~min}$ to give a colourless precipitate, which was filtered and washed with cold water. Purification by recrystallization $(95 \% \mathrm{EtOH})$ gave $(E)-2-(2-$ hydroxybenzylidene)hydrazinecarbothioamide (7a). A similar procedure was employed for the preparation of the other 2-(benzylidene)hydrazinecarbothioamides $\mathbf{7 b}$-f.

(E)-2-(2-Hydroxybenzylidene)hydrazinecarbothioa mide (7a) (0.68 g, 70\%) was obtained as colourless crystals, mp $208-210^{\circ} \mathrm{C}$ (Lit. mp $210^{\circ} \mathrm{C}$ [49]); IR ( $\left.\mathrm{KBr}\right) v_{\max }$ 3462, $3415\left(\mathrm{NH}_{2}\right), 3374(\mathrm{OH}), 3215(\mathrm{NH}), 1610(\mathrm{C}=\mathrm{N})$, $1230(\mathrm{C}=\mathrm{S})$; with identical spectroscopic properties. (E)2-(3-Hydroxybenzylidene)hydrazinecarbothioamide (7b) $(0.80 \mathrm{~g}, 82 \%)$ was obtained as light brown crystals, $\mathrm{mp}$ $166-168^{\circ} \mathrm{C}$ (Lit. $\mathrm{mp} 168-170^{\circ} \mathrm{C}$ [50]); IR (KBr) $v_{\max }$ 3458, $3409\left(\mathrm{NH}_{2}\right), 3365(\mathrm{OH}), 3260(\mathrm{NH}), 1614(\mathrm{C}=\mathrm{N})$, $1225(\mathrm{C}=\mathrm{S})$; with identical spectroscopic properties. (E)2-(4-Hydroxybenzylidene)hydrazinecarbothioamide (7c) $(0.69 \mathrm{~g}, 71 \%)$ was obtained as colourless crystals, $\mathrm{mp} 214-$ $216^{\circ} \mathrm{C}$ (Lit. mp $218-219^{\circ} \mathrm{C}$ [46]); IR (KBr) $v_{\max } 3469,3414$ $\left(\mathrm{NH}_{2}\right), 3377(\mathrm{OH}), 3235(\mathrm{NH}), 1610(\mathrm{C}=\mathrm{N}), 1231(\mathrm{C}=\mathrm{S})$; with identical spectroscopic properties. (E)-2-(5-Bromo2-hydroxybenzylidene)hydrazinecarbothioamide (7e) $(1.10 \mathrm{~g}, 78 \%)$ was obtained as a beige solid, mp 234$236^{\circ} \mathrm{C}$ (Lit. $\mathrm{mp} 238.5^{\circ} \mathrm{C}$ [51]); IR (KBr) $v_{\max } 3543$, $3429\left(\mathrm{NH}_{2}\right), 3317(\mathrm{OH}), 3253(\mathrm{NH}), 1612(\mathrm{C}=\mathrm{N})$, $1217(\mathrm{C}=\mathrm{S})$; with identical spectroscopic properties. (E)-2-(2-Hydroxy-3-methoxybenzylidene)hydrazinecarbothioamide (7f) $(0.80 \mathrm{~g}, 72 \%)$ was obtained as a colourless solid, $\mathrm{mp} 222-224^{\circ} \mathrm{C}$ (Lit. mp $220-222^{\circ} \mathrm{C}$ [52]); IR (KBr) $v_{\max } 3458,3424\left(\mathrm{NH}_{2}\right), 3342(\mathrm{OH})$, $3164(\mathrm{NH}), 1594(\mathrm{C}=\mathrm{N}), 1140(\mathrm{C}=\mathrm{S})$; with identical spectroscopic properties.
General procedure for the synthesis of 2-(naphthalen-1ylmethylene)hydrazinecarbothioamides 9

The experimental procedure employed for the synthesis of (E)-2-(2-hydroxybenzylidene)hydrazinecarbothioamide (7a) was employed using naphthaldehyde $8(5.0 \mathrm{mmol})$, thiosemicarbazide (5) $(5.0 \mathrm{mmol})$ and absolute EtOH. Purification by recrystallization, using EtOH-EtOAc (1:2), gave the target compound (9a,b). (E)-2-(Naphthalen-1-ylmethylene) hydrazinecarbothioamide (9a) (1.05 g, 92\%) was obtained as a yellow solid, $\mathrm{mp} 138-140^{\circ} \mathrm{C}$ (Lit. $\mathrm{mp} 126^{\circ} \mathrm{C}$ [53]); IR $(\mathrm{KBr}) v_{\max } 3448,3412\left(\mathrm{NH}_{2}\right), 3228(\mathrm{NH}), 1592(\mathrm{C}=\mathrm{N})$, $1249(\mathrm{C}=\mathrm{S})$; with identical spectroscopic properties. (E)-2[(2-Hydroxynaphthalen-1-yl)methylene]hydrazinecarbo thioamide (9b) $(0.88 \mathrm{~g}, 72 \%)$ was obtained as a pink-yellow solid, mp $272-274^{\circ} \mathrm{C}$ (Lit. mp $271^{\circ} \mathrm{C}$ [54]); IR (KBr) $v_{\max }$ 3550, $3426\left(\mathrm{NH}_{2}\right), 3236(\mathrm{NH}), 3148(\mathrm{OH}), 1589(\mathrm{C}=\mathrm{N})$, $1226(\mathrm{C}=\mathrm{S})$; with identical spectroscopic properties.

\section{Synthesis of hydrazinyl thiazolyl coumarin derivatives}

10a-f from bezylidenethiosemicabazides 7a-f

A stirred solution of 3-bromoacetylcoumarin (4) $(107 \mathrm{mg}$, $0.40 \mathrm{mmol}$ ) and benzylidenethiosemicarbazone $7 \mathbf{a}-\mathbf{f}$ (78 $\mathrm{mg}, 0.40 \mathrm{mmol}$ ) in $\mathrm{EtOH}$ was heated at $60^{\circ} \mathrm{C}$ for $10 \mathrm{~min}$ (hold time) under microwave irradiation and then cooled in a stream of compressed air to give a thick yellow precipitate. The reaction mixture was neutralized with aqueous ammonium hydroxide solution (5\%) and the precipitated solid was filtered. Purification by recrystallization, using $\mathrm{CHCl}_{3}-\mathrm{EtOH}$

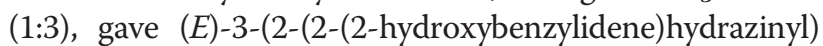
thiazol-4-yl)-2H-chromen-2-one (10a). A similar procedure was employed to prepare the target compounds $\mathbf{1 0 b}-\mathbf{h}$, after purification by recrystallization using $\mathrm{CHCl}_{3}, \mathrm{EtOH}$ or EtOAc-EtOH.

(E)-3-\{2-[2-(2-Hydroxybenzylidene)hydrazinyl]thiazol4-yl\}-2H-chromen-2-one (10a)

The title compound (10a) (107 mg, 74\%) was obtained after purification by recrystallization, using $\mathrm{CHCl}_{3}-\mathrm{EtOH}$ (1:3), as a yellow solid, $\mathrm{mp} 270-272^{\circ} \mathrm{C}$ (Lit. mp $270-272^{\circ} \mathrm{C}$ [20]); IR (KBr) $v_{\max } 3420(\mathrm{NH}), 3212(\mathrm{OH}), 1699$ $(\mathrm{O}-\mathrm{C}=\mathrm{O}), 1603(\mathrm{C}=\mathrm{N}) ;{ }^{1} \mathrm{H}$ NMR $\left(400 \mathrm{MHz}\right.$, DMSO- $\left.d_{6}\right)$ $\delta 12.30(1 \mathrm{H}, \mathrm{br} \mathrm{s}), 10.41(1 \mathrm{H}, \mathrm{br} \mathrm{s}), 8.55(1 \mathrm{H}, \mathrm{s}), 8.29(1 \mathrm{H}$, s), $7.87(1 \mathrm{H}, \mathrm{dd}, J=7.5,1.2 \mathrm{~Hz}), 7.77(1 \mathrm{H}, \mathrm{s}), 7.65(1 \mathrm{H}, \mathrm{dd}$, $J=8.0,1.1 \mathrm{~Hz}), 7.64(1 \mathrm{H}, \mathrm{ddd}, J=8.2,7.5,1.2 \mathrm{~Hz}), 7.47$ $(1 \mathrm{H}, \mathrm{d}, J=8.2 \mathrm{~Hz}), 7.40(1 \mathrm{H}, \mathrm{t}, J=7.5 \mathrm{~Hz}), 7.37(1 \mathrm{H}, \mathrm{td}$, $J=8.0,1.1 \mathrm{~Hz}), 6.91(1 \mathrm{H}, \mathrm{d}, J=8.0 \mathrm{~Hz}), 6.89(1 \mathrm{H}, \mathrm{t}$, $J=8.0 \mathrm{~Hz})$.

(E)-3-\{2-[2-(3-Hydroxybenzylidene)hydrazinyl]thiazol4-yl\}-2H-chromen-2-one (10b)

The title compound (10b) (116 mg, 80\%) was obtained after purification by recrystallization, using EtOAc-EtOH (1:2), as bright yellow crystals, $\mathrm{mp} 253-254^{\circ} \mathrm{C}$ (Lit. mp 254-256 ${ }^{\circ} \mathrm{C}$ [20]); IR (KBr) $v_{\max } 3365(\mathrm{NH}), 3262(\mathrm{OH})$, $1698(\mathrm{O}-\mathrm{C}=\mathrm{O}), 1602(\mathrm{C}=\mathrm{N}) ;{ }^{1} \mathrm{H}$ NMR $(400 \mathrm{MHz}$, 
DMSO- $\left.d_{6}\right) \delta 12.18$ (1H, br s), $9.63(1 \mathrm{H}$, br s), $8.55(1 \mathrm{H}, \mathrm{s})$, $7.98(1 \mathrm{H}, \mathrm{s}), 7.87(1 \mathrm{H}, \mathrm{dd}, J=7.6,0.9 \mathrm{~Hz}), 7.78(1 \mathrm{H}, \mathrm{s})$, $7.64(1 \mathrm{H}$, ddd, $J=8.2,7.6,0.9 \mathrm{~Hz}), 7.46(1 \mathrm{H}, \mathrm{d}, J=8.2 \mathrm{~Hz})$, $7.40(1 \mathrm{H}, \mathrm{t}, J=7.6 \mathrm{~Hz}), 7.23(1 \mathrm{H}, \mathrm{t}, J=7.8 \mathrm{~Hz}), 7.12(1 \mathrm{H}, \mathrm{s})$, $7.05(1 \mathrm{H}, \mathrm{d}, J=7.8 \mathrm{~Hz}), 6.80(1 \mathrm{H}, \mathrm{dd}, J=7.8,2.4 \mathrm{~Hz})$.

(E)-3-\{2-[2-(4-Hydroxybenzylidene)hydrazinyl]thiazol4-yl\}-2H-chromen-2-one (10c)

The title compound (10c) (103 mg, 71\%) was obtained after purification by recrystallization, using $\mathrm{CHCl}_{3}-$ EtOH (1:3), as brown crystals, mp: $249-251^{\circ} \mathrm{C}$ (Lit. mp 249-250 $\left.{ }^{\circ} \mathrm{C}[20]\right)$; IR $(\mathrm{KBr}) v_{\max } 3424(\mathrm{NH}), 3212(\mathrm{OH})$, $1706(\mathrm{O}-\mathrm{C}=\mathrm{O}), 1605(\mathrm{C}=\mathrm{N})$; ${ }^{1} \mathrm{H}$ NMR $(400 \mathrm{MHz}$, DMSO- $\left.d_{6}\right) \delta 12.05$ (1H, br s), 9.93 (1H, br s), $8.60(1 \mathrm{H}, \mathrm{s})$, $7.93(1 \mathrm{H}, \mathrm{s}), 7.81(1 \mathrm{H}, \mathrm{dd}, J=7.6,1.0 \mathrm{~Hz}), 7.72(1 \mathrm{H}, \mathrm{s})$, $7.67(1 \mathrm{H}$, ddd, $J=8.2,7.6,1.0 \mathrm{~Hz}), 7.55(2 \mathrm{H}, \mathrm{d}, J=8.6 \mathrm{~Hz})$, $7.48(1 \mathrm{H}, \mathrm{d}, J=8.2 \mathrm{~Hz}), 7.44(1 \mathrm{H}, \mathrm{t}, J=7.6 \mathrm{~Hz}), 6.88(2 \mathrm{H}, \mathrm{d}$, $J=8.6 \mathrm{~Hz})$.

(E)-3-\{2-[2-(2-Hydroxy-5-bromobenzylidene) hydrazinyl]thiazol-4-yl)-2H-chromen-2-one (10e)

The title compound (10e) (127 mg, 72\%) was obtained after purification by recrystallization, using EtOAc$\mathrm{EtOH}$ (3:1), as a yellow solid, mp: $295-296^{\circ} \mathrm{C}$ (Lit. mp 296-298 $\left.{ }^{\circ} \mathrm{C}[20]\right)$; IR ( $\left.\mathrm{KBr}\right) v_{\max } 3430(\mathrm{NH}), 3260(\mathrm{OH})$, $1701(\mathrm{O}-\mathrm{C}=\mathrm{O}), 1583(\mathrm{C}=\mathrm{N})$; ${ }^{1} \mathrm{H}$ NMR $(400 \mathrm{MHz}$, DMSO- $\left.d_{6}\right) \delta 12.30(1 \mathrm{H}$, br s), $10.45(1 \mathrm{H}$, br s), $8.57(1 \mathrm{H}$, s), $8.32(1 \mathrm{H}, \mathrm{s}), 7.88(1 \mathrm{H}, \mathrm{dd}, J=7.5,1.1 \mathrm{~Hz}), 7.81(1 \mathrm{H}$, s), $7.79(1 \mathrm{H}, \mathrm{d}, J=2.5 \mathrm{~Hz}), 7.68(1 \mathrm{H}$, ddd, $J=8.3,7.5$, $1.1 \mathrm{~Hz}), 7.50(1 \mathrm{H}, \mathrm{d}, J=8.3 \mathrm{~Hz}), 7.44(1 \mathrm{H}, \mathrm{t}, J=7.5 \mathrm{~Hz})$, $7.38(1 \mathrm{H}, \mathrm{dd}, J=8.5,2.5 \mathrm{~Hz}), 6.87(1 \mathrm{H}, \mathrm{d}, J=8.5 \mathrm{~Hz})$.

(E)-3-\{2-[2-(2-Hydroxy-3-methoxybenzylidene) hydrazinyl]thiazol-4-yl\}-2H-chromen-2-one (10f)

The title compound (10f) (113 mg, 72\%) was obtained after purification by recrystallization, using EtOAc-EtOH (2:1), as a brown solid, mp $266-267^{\circ} \mathrm{C}$ (Lit. mp $266^{\circ} \mathrm{C}$ [20]); IR (KBr) $v_{\max } 3445(\mathrm{NH}), 3239(\mathrm{OH}), 1704$ $(\mathrm{O}-\mathrm{C}=\mathrm{O}), 1600(\mathrm{C}=\mathrm{N})$; ${ }^{1} \mathrm{H}$ NMR $(400 \mathrm{MHz}, \mathrm{DMSO}-$ $\left.d_{6}\right) \delta 12.18(1 \mathrm{H}$, br s), $9.45(1 \mathrm{H}$, br s $), 8.56(1 \mathrm{H}, \mathrm{s}), 8.39$ $(1 \mathrm{H}, \mathrm{s}), 7.87(1 \mathrm{H}, \mathrm{dd}, J=7.5,0.9 \mathrm{~Hz}), 7.78(1 \mathrm{H}, \mathrm{s}), 7.62$ $(1 \mathrm{H}$, ddd, $J=8.3,7.5,0.9 \mathrm{~Hz}), 7.46(1 \mathrm{H}, \mathrm{d}, J=8.3 \mathrm{~Hz}), 7.41$ $(1 \mathrm{H}, \mathrm{t}, J=7.5 \mathrm{~Hz}), 7.27(1 \mathrm{H}, \mathrm{d}, J=8.0 \mathrm{~Hz}), 6.99(1 \mathrm{H}, \mathrm{d}$, $J=8.0 \mathrm{~Hz}), 6.84(1 \mathrm{H}, \mathrm{t}, J=8.0 \mathrm{~Hz}), 3.83(3 \mathrm{H}, \mathrm{s})$.

\section{Synthesis of hydrazinyl thiazolyl coumarin derivatives $10 \mathrm{~g}$,h from (naphthalenylmethylene)thiosemicabazides $9 a, b$}

The title compound was synthesized by a similar procedure described for the synthesis of 10a-f, using 3bromoacetylcoumarin (4) with naphthalenylmethylene) thiosemicabazide $\mathbf{9 a , b}$.

(E)-3-\{2-[2-(1-Naphthylidene)hydrazinyl]thiazol-4-yl\}2H-chromen-2-one (10g)

The title compound (10g) (114 mg, 71\%) was obtained after purification by recrystallization, using EtOAc-EtOH (3:1), as a yellow solid, mp $262-264^{\circ} \mathrm{C}$ (Lit. mp $262-265^{\circ} \mathrm{C}$
[20]; 240-242 ${ }^{\circ} \mathrm{C}$ [15]); IR (KBr) $v_{\max } 3424(\mathrm{NH}), 1702(\mathrm{O}-$ $\mathrm{C}=\mathrm{O}), 1594(\mathrm{C}=\mathrm{N}) ;{ }^{1} \mathrm{H}$ NMR $\left(400 \mathrm{MHz}, \mathrm{DMSO}-d_{6}\right) \delta$ $12.35(1 \mathrm{H}$, br s), $8.79(1 \mathrm{H}, \mathrm{d}, J=8.5 \mathrm{~Hz}), 8.71(1 \mathrm{H}, \mathrm{s}), 8.59$ $(1 \mathrm{H}, \mathrm{s}), 8.01(2 \mathrm{H}, \mathrm{t}, J=7.8 \mathrm{~Hz}), 7.88(2 \mathrm{H}, \mathrm{d}, J=7.6 \mathrm{~Hz})$, $7.83(1 \mathrm{H}, \mathrm{s}), 7.67(1 \mathrm{H}$, ddd, $J=8.1,7.5,0.9 \mathrm{~Hz}), 7.63(1 \mathrm{H}, \mathrm{t}$, $J=8.5 \mathrm{~Hz}), 7.62(2 \mathrm{H}, \mathrm{dd}, J=7.8,1.8 \mathrm{~Hz}), 7.49(1 \mathrm{H}, \mathrm{d}$, $J=8.1 \mathrm{~Hz}), 7.41(1 \mathrm{H}, \mathrm{t}, J=7.5 \mathrm{~Hz})$.

(E)-3-\{2-[2-(2-Hydroxynaphthylidene)hydrazinyl] thiazol-4-yl\}-2H-chromen-2-one (10h)

The title compound (10h) (119 mg, 79\%) was obtained after purification by recrystallization, using EtOAc-EtOH (2:1), as a brown solid, mp $271-273^{\circ} \mathrm{C}$, (Lit. mp $272-274^{\circ} \mathrm{C}$ [20]); IR (KBr) $v_{\max } 3439(\mathrm{NH}), 3207(\mathrm{NH}), 1705(\mathrm{O}-$ $\mathrm{C}=\mathrm{O}), 1602(\mathrm{C}=\mathrm{N}) ;{ }^{1} \mathrm{H}$ NMR $\left(400 \mathrm{MHz}, \mathrm{DMSO}-d_{6}\right) \delta$ $12.25(1 \mathrm{H}$, br s), $10.92(1 \mathrm{H}$, br s), $8.99(1 \mathrm{H}, \mathrm{s}), 8.78(1 \mathrm{H}, \mathrm{d}$, $J=8.6 \mathrm{~Hz}), 8.59(1 \mathrm{H}, \mathrm{s}), 7.90-7.81(3 \mathrm{H}, \mathrm{m}), 7.82(1 \mathrm{H}, \mathrm{s}), 7.63$ $(1 \mathrm{H}$, ddd, $J=8.2,7.5,1.5 \mathrm{~Hz}), 7.58(1 \mathrm{H}, \mathrm{t}, J=7.5 \mathrm{~Hz}), 7.48$ $(1 \mathrm{H}, \mathrm{d}, J=8.2 \mathrm{~Hz}), 7.42(2 \mathrm{H}, \mathrm{ddd}, J=8.2,7.2,4.0 \mathrm{~Hz}), 7.24$ $(1 \mathrm{H}, \mathrm{d}, J=8.4 \mathrm{~Hz})$.

\section{Methods}

${ }^{1} \mathrm{H}$ and ${ }^{13} \mathrm{C}$ NMR spectra were obtained using $d_{6}$-dimethyl sulfoxide at $25^{\circ} \mathrm{C}$ using a Bruker DPX 400 instrument or 500 Avance instrument operating at 400 or $500 \mathrm{MHz}$ for ${ }^{1} \mathrm{H}$ spectra and $100 \mathrm{MHz}$ for ${ }^{13} \mathrm{C}$ spectra, unless stated otherwise, and were reported in ppm; $J$ values were recorded in $\mathrm{Hz}$ and multiplicities were expressed by the usual conventions ( $\mathrm{s}=$ singlet, $\mathrm{d}=$ doublet, $\mathrm{t}=$ triplet, app = apparent, $\mathrm{m}=$ multiplet). Infra-red (IR) spectra were recorded in the range $4000-600 \mathrm{~cm}^{-1}$ on a Perkin-Elmer 1600 series FTIR spectrometer using $\mathrm{KBr}$ disks and are reported in $\mathrm{cm}^{-1}$. All compounds were examined by analytical thin layer chromatography carried out using aluminium-backed plates coated with Merck Kieselgel 60 $\mathrm{GF}_{254}$, eluting with hexane-ethyl acetate $(3: 1, v / v)$, that were visualised under UV light (at 254 and/or $360 \mathrm{~nm}$ ). Microwave-assisted syntheses were carried out at the recorded temperature by the modulation of the initial magnetron power (given in parentheses) in a sealed tube using a CEM Discover single-mode instrument, with magnetic stirring and temperature measurement using the inbuilt IR sensor. Melting points (mp) were determined on a Kofler hot stage apparatus and are uncorrected. Commercially available reagents were used without further purification; solvents were dried by standard procedures.

\section{DPPH radical-scavenging activity}

DPPH radical-scavenging activity of the samples was assessed by our reported method [43] with minor modifications. The 1,1-diphenyl-2-picrylhydrazyl radical solution was prepared by dissolving an appropriate amount of $\mathrm{DPPH}$ in $\mathrm{MeOH}$ to give a concentration of $1 \mathrm{mM}$. The $\mathrm{DPPH}$ radical solution $(1 \mathrm{mM} ; 0.5 \mathrm{~mL})$ was added to a solution of the compound to be tested in $\mathrm{MeOH}(4 \mathrm{~mL})$ 
at various concentrations (to give a final concentration of $\mathrm{DPPH}$ of $0.11 \mathrm{mM}$ ). The mixture was shaken vigorously and incubated at room temperature in the dark for $30 \mathrm{~min}$. The decrease in the absorbance of the resulting solution was then measured spectrophotometrically at $v$ $517 \mathrm{~nm}$. All measurements were made in triplicate. Two controls were used for this test: a negative control (blank) consisting of $\mathrm{MeOH}(4 \mathrm{~mL})$ and the DPPH radical solution $(0.5 \mathrm{~mL})$ and a positive control comprising the reference anti-oxidant (quercetin or $\mathrm{BHT}$ ) in $\mathrm{MeOH}$ and DPPH radical solution. Inhibition of free radical $\mathrm{DPPH}$ in percentage was calculated as follows:

$$
\begin{aligned}
& \text { Radical scavenging activity }(\%) \\
& \quad=\left(A_{\text {blank }}-A_{\text {sample }} / A_{\text {blank }}\right) \times 100
\end{aligned}
$$

Where $A_{\text {blank }}$ is the absorbance of negative control (containing all reagents except test compounds) and $A_{\text {sample }}$ is the absorbance of the test compounds and all the reagents. Sample concentration providing 50\% inhibition $\left(\mathrm{IC}_{50}\right)$ was calculated by plotting the inhibition percentage against sample concentration. All the synthesized compounds were evaluated for DPPH radical scavenging ability and the antioxidant activity of the synthesized compounds was compared with a synthetic antioxidant BHT (butylated hydroxytoluene) and a natural antioxidant quercetin, as the reference standards.

\section{$\mathrm{ABTS}^{+}$radical cation-scavenging activity}

According to a modified method from Arnao et al. [45], a solution of ABTS $(7.4 \mathrm{mM})$ in $\mathrm{MeOH}$ and a solution of potassium persulphate $(2.6 \mathrm{mM})$ in $\mathrm{MeOH}$ were mixed in equal volumes and allowed to react for 12 hours in the dark at room temperature. The resulting solution $(1.0 \mathrm{~mL})$ was diluted (to a volume of $30.0 \mathrm{~mL}$ ) by the addition of methanol to give an $\mathrm{ABTS}^{+}{ }^{+}$concentration of $0.12 \mathrm{mM}$ and absorbance of $1.1 \pm 0.02$ at $734 \mathrm{~nm}$. A portion of the ABTS $^{++}$solution $(3.0 \mathrm{~mL})$ was added to a methanolic solution $(150 \mu \mathrm{L})$ of the compound to be tested at various concentrations and the resulting mixture was incubated in the dark for 2 hours. The absorbance of each solution was recorded at $734 \mathrm{~nm}$. All measurements were made in triplicate and for each assay a fresh $\mathrm{ABTS}^{+}$stock solution was prepared. Radical scavenging activity was calculated in a similar fashion to the DPPH radical-scavenging assays. The $\mathrm{IC}_{50}$ value of each compound was calculated by plotting the inhibition percentage against concentration of the tested compounds and the results were expressed in $\mu \mathrm{M}$.

\section{Competing interests}

The authors declare that they have no competing interests.

\section{Authors' contributions}

$\mathrm{HO}$ and $\mathrm{AA}$ participated in study design and coordination, manuscript preparation and carried out the synthetic experiments, MCB and $\mathrm{KCL}$ participated in study design and coordination and manuscript preparation. All authors read and approved the final manuscript.

\section{Acknowledgements}

This work was supported by the Universiti Sains Malaysia (USM) for a fellowship award to $\mathrm{HO}$, the Universiti Sains Malaysia fellowship for financial support of $A A$, and grants from the SPARC initiative (award to MCB) and RU grant [1001/PKimia/811133] to conduct antioxidant research work (award to AA).

\section{Author details}

'School of Chemical Sciences, Universiti Sains Malaysia, 11800, Penang, Malaysia. ${ }^{2}$ School of Pharmaceutical Sciences, Universiti Sains Malaysia, 11800 Penang, Malaysia. ${ }^{3}$ Department of Chemistry, School of Life Sciences, University of Sussex, Brighton BN1 9QJ, UK.

Received: 26 October 2011 Accepted: 10 February 2012 Published: 17 April 2012

\section{References}

1. O'Kennedy R, Thornes RD: Coumarins: biology, applications, and mode of action, John Wiley \& Sons, Chichester; New York, 1997.

2. Bullock SJ, Felton CE, Fennessy RV, Harding LP, Andrews M, Pope SJA, Rice CR, Riis-Johannessen T: Coumarin-based luminescent ligand that forms helicates with dicationic metal ions. Dalton Trans 2009, 47:10570-10573.

3. Ghazaryan A, Khatchadouria A, Karagyozyan M, Kachatryan A, Sekoyan E, Bdoyan $\mathrm{H}$, Melkumyan $\mathrm{H}$, Karageuzyan K: Peculiarities of the anticoagulant properties for the newly synthesized preparations of coumarin related compounds. Cardiovasc Hematol Disord Drug Targets 2007, 7:170-173.

4. Kancheva VD, Boranova PV, Nechev JT, Manolov II: Structure-activity relationships of new 4-hydroxy bis-coumarins as radical scavangers and chain breaking antioxidants. Biochimie 2010, 92:1138-1146.

5. Morabito GDT, Singh B, Prasad AK, Parmar VS, Naccari FM, Saija A, Cristani $M$, Firuzi O, Saso L: Antioxidant properties of 4-methyl coumarins in in vitro cell-free systems. Biochimie 2010, 92:1107-1117.

6. Grimm E, Brideau C, Chauret N, Chan C, Delorme D, Ducharme Y, Ethier D, Falgueyret J, Friesen R, Guay J: Substituted coumarins as potent 5lipoxygenase inhibitors. Bioorg Med Chem Lett 2006, 16:2528-2531.

7. Marion R, Alois S, Zhong-liang C, Rudolf B: 5-Lipoxygenase and cyclooxygenase inhibitory active compounds from Atractylodes lancea. J Nat Prod 1998, 61:347-350.

8. Lafitte D, Lamour V, Tsvetkov P, Makarov A, Klich M, Deprez P, Moras D, Briand C, Gilli R: DNA gyrase interaction with coumarin-based inhibitors: the role of the hydroxybenzoate isopentenyl moiety and the 5 '-methyl group of the novioset. Biochemistry 2002, 41:7217-7223.

9. Montagnev C, de Souza S, Groposoa C, Delle Monache F, Smania E, Smania A: Antifungal activity of coumarins. J Biosci 2008, 63:21-28.

10. Kostova I: Synthetic and natural coumarins as cytotoxic agents. Curr Med Chem Anti Canc Agents 2005, 5:29-46.

11. Siddiqui $N$, Arshad M, Khan S: Synthesis of some new coumarin incorporated thiazolyl semicarbazones as anticonvulsants. Acta Pol Pharm Drug Res 2009, 66:161-167.

12. Kamal A, Adil S, Tamboli J, Siddardha B, Murthy U: Synthesis of coumarin linked naphthalimide conjugates as potential anticancer and antimicrobial agents. Lett Drug Des Discov 2009, 6:201-209.

13. Kalkhambkar R, Kulkarni G, Shivkumar H, Rao R: Synthesis of novel triheterocyclic thiazoles as anti-inflammatory and analgesic agents. Eur J Med Chem 2007, 42:1272-1276.

14. Gursoy A, Karali N: Synthesis, characterization and primary antituberculosis activity evaluation of 4-(3-coumarinyl)-3-benzyl-4thiazolin-2-one benzylidenehydrazones. Turk J Chem 2003, 27:545-552.

15. Chimenti F, Bizzarri B, Bolasco A, Secci D, Chimenti P, Granese A, Carradori S, D'Ascenzio M, Scaltrito MM, Sisto F: Synthesis and anti Helicobacter pylori activity of 4-(coumarin-3-yl)-thiazol-2-ylhydrazone derivatives. J Heterocycl Chem 2010, 47:1269-1274.

16. Valko M, Leibfritz D, Moncol J, Cronin MT, Mazur M, Telser J: Free radicals and antioxidants in normal physiological functions and human disease. Int J Biochem Cell Biol 2007, 39:44-84.

17. Rhee $\mathrm{SG}: \mathrm{H}_{2} \mathrm{O}_{2}$, a necessary evil for cell signalling. Science 2006 , 312:1882-1883. 
18. Sies H: Oxidative stress: oxidants and antioxidants. Exp Physio/ 1997, 82:291-295

19. Fylaktakidou K, Hadjipavlou-Litina D, Litinas K, Nicolaides D: Natural and synthetic coumarin derivatives with anti-inflammatory/antioxidant activities. Curr Pharm Des 2004, 10:3813-3833.

20. Arshad A, Osman H, Bagley MC, Chan K, Mohamad S, Zahariluddin ASM: Synthesis and antimicrobial properties of some new thiazolyl coumarin derivatives. Eur J Med Chem 2011, 46:3788-3794.

21. Arshad A, Osman H, Chan K, Yeap C, Fun HK: 3-\{2-[2-(Diphenylmethylene) hydrazinyl] thiazol-4-yl\}-2H-chromen-2-one. Acta Crystallogr Sect E: Struct Rep Online 2010, 66:01788-01789.

22. Arshad A, Osman H, Chan K, Goh JH, Fun HK: 3-\{2-[2-(3Hydroxybenzylidene)-hydrazin-1-yl]-1,3-thiazol-4-yl\}-2H-chromen-2-one hemihydrate. Acta Crystallogr Sect E: Struct Rep Online 2010, 66:01498-01499.

23. Arshad A, Osman H, Chan K, Hemamalini M, Fun HK: (E)-3-(2-\{2-[1-(3Hydroxyphenyl)ethylidene]hydrazinyl\}-1, 3-thiazol-4-yl)-2H-chromen-2-one. Acta Crystallogr Sect E: Struct Rep Online 2011, 67:01072-01073.

24. Arshad A, Osman H, Chan K, Hemamalini M, Fun HK: (E)-6-Bromo-3-(2-(2-(2chlorobenzylidene)hydrazinyl)thiazol-5-yl)-2H-chromen-2-one dimethylsulfoxide monosolvate. Acta Crystallogr Sect E: Struct Rep Online 2011, 67:01009-01010.

25. Kappe CO, Stadler A: Microwaves in Organic and Medicinal Chemistry. Wiley-VCH: Weinheim; 2005

26. Kappe CO, Dallinger D: The impact of microwave synthesis on drug discovery. Nat Rev Drug Discov 2006, 5:51-63.

27. Alcázar J, Oehlrich D: Recent applications of microwave irradiation to medicinal chemistry. Future Med Chem 2010, 2:169-176.

28. Collins JM, Leadbeater NE: Microwave energy: a versatile tool for the biosciences. Org Biomol Chem 2007, 5:1141-1150.

29. Merritt E, Bagley MC: Holzapfel-Meyers-Nicolaou modification of the Hantzsch thiazole synthesis. Synthesis 2007, 22:3535-3541.

30. Merritt EA, Bagley MC: Synthesis of the central heterocyclic domain of micrococcin P1. Synlett 2007, 6:954-958.

31. Bogdal D: Coumarins: fast synthesis by Knoevenagal condensation under microwave irradiation. J Chem Res-S 1998, 468-469.

32. Ajani OO, Nwinyi OC: Microwave-assisted synthesis and evaluation of antimicrobial activity of 3-\{3-(s-aryl and s-heteroaromatic)acryloyl\}- $2 \mathrm{H}-$ chromen-2-one derivatives. J Heterocyclic Chem 2010, 47:179-187.

33. Bowman MD, Schmink JR, McGowan CM, Kormos CM, Leadbeater NE: Scale-up of microwave-promoted reactions to the multigram level using a sealed-vessel microwave apparatus. Org Process Res Dev 2008, 12:1078-1088.

34. Schmink JR, Kormos CM, Devine WG, Leadbeater NE: Exploring the scope for scale-up of organic chemistry using a large batch microwave reactor. Org Process Res Dev 2010, 14:205-214.

35. Venogopala KN, Jayashree BS: Microwave-induced synthesis of Schiff bases of aminothiazolyl bromocoumarins as antibacterials. Indian J Pharm Sci 2008, 70:88-91.

36. Karade NN, Gampawar SV, Shinde SV, Jadhav WN: L-Proline catalyzed solvent-free knoevenagel condensation for the synthesis of 3-substituted coumarins. Chin J Chem 2007, 25:1686-1689.

37. Gaikwad SA, Patil AA, Deshmukh MB: An efficient, uncatalyzed, and rapid synthesis of thiazoles and aminothiazoles under microwave irradiation and investigation of their biological activity. Phosphorus Sulfur 2010, 185:103-109.

38. Hughes RA, Thompson SP, Alcaraz L, Moody CJ: Total synthesis of the thiopeptide antibiotic amythiamicin D. J Am Chem Soc 2005, 127:15644-15651.

39. Kiryanov AA, Sampson P, Seed AJ: Synthesis of 2-alkoxy-substituted thiophenes, 1,3-thiazoles, and related S-heterocycles via Lawesson's reagent-mediated cyclization under microwave irradiation: applications for liquid crystal synthesis. J Org Chem 2001, 66:7925-7929.

40. Romagnoli R, Baraldi PG, Lopez OC, Carrion MD, Cara CL, Preti D, Tabrizi MA Balzarini J: Microwave-assisted synthesis of substituted 2,4-diarylthiazoles and their evaluation as anticancer agents. Lett Drug Des Discov 2007, 4:464-466.

41. Shih M, Su Y, Wu C: Syntheses of aromatic substituted hydrazino-thiazole derivatives to clarify structural characterization and antioxidant activity between 3-arylsydnonyl and aryl substituted hydrazino-thiazoles. Chem Pharm Bull 2007, 55:1126-1135.
42. Liu Z-Q: Chemical methods to evaluate antioxidant ability. Chem Rev 2010, 110:5675-5691.

43. Rahim A, Rocca E, Steinmetz J, Kassim MJ, Ibrahim MS, Osman H: Antioxidant activity of mangrove Rhizophora apiculata bark extracts. Food Chem 2008, 107:200-207.

44. Huang D, Ou B, Prior RL: The chemistry behind antioxidant capacity assays. J Agric Food Chem 2005, 53:1841-1856.

45. Arnao MB, Cano A, Acosta M: The hydrophilic and lipophilic contribution to total antioxidant activity. Food Chem 2001, 73:239-244.

46. Arts MJTJ, Haenen GRMM, Voss H-P, Bast A: Antioxidant capacity of reaction products limits the applicability of the Trolox Equivalent Antioxidant Capacity (TEAC) assay. Food Chem Toxicol 2004, 42:45-49.

47. Awika JM, Rooney LW, Wu X, Prior RL, Cisneros-Zevallos L: Screening methods to measure antioxidant activity of sorghum (Sorghum bicolor) and Sorghum products. J Agric Food Chem 2003, 51:6657-6662.

48. Valizadeh H, Gholipur H, Shockravi A: Microwave assisted synthesis of coumarins via potassium carbonate catalyzed knoevenage condensation in $1 \mathrm{n}$ butyl 3 methylimidazolium bromide ionic liquid. J Heterocyclic Chem 2007, 44:867-870.

49. Kostas ID, Andreadaki FJ, Kovala-Demertzi D: Suzuki-Miyaura crosscoupling reaction of aryl bromides and chlorides with phenylboronic acid under aerobic conditions catalyzed by palladium complexes with thiosemicarbazone ligands. Tetrahedron Lett 2005, 46:1967-1970.

50. Yi W, Cao RH, Chen ZY, Yu L, Ma L, Song HC: Design, synthesis and biological evaluation of hydroxy-or methoxy-substituted phenylmethylenethiosemicarbazones as tyrosinase inhibitors. Chem Pharm Bull 2009, 57:1273-1277.

51. Güveli S, Bal-Demirci T, Özdemir N, Ülküseven B: Nickel(II) complexes of ONS and ONN chelating thiosemicarbazones with triphenylphosphine co-ligands. Transition Met Chem 2009, 34:383-388.

52. Kumar AP, Reddy KPPRM, Reddy TV, Reddy PR, Reddy VK: Synthesis and characterisation of 2-hydroxy-3-methoxy benzaldehyde thiosemicarbazone (HMBATSC) and its application of simultaneous second order derivative spectrophotometric method for determination of cobalt(II), nickel(II) and vanadium(V). Main Group Chem 2006, 5:141-151

53. Jensen $\mathrm{KA}$, Jensen $\mathrm{CL}$ : Thiohydrazides and thiohydrazones: a new class of antibacterial substances. Acta Chem Scand 1952, 6:957-958.

54. Yilmaz I, Çukurovali A: Cobalt(II), copper(II), nickel(II), and zinc(II) complexes of naphthaldehyde thiazolyl hydrazones. Pol J Chem 2004, 78:663-672

doi:10.1186/1752-153X-6-32

Cite this article as: Osman et al:: Microwave-assisted synthesis and antioxidant properties of hydrazinyl thiazolyl

coumarin derivatives. Chemistry Central Journal 2012 6:32.

Publish with ChemistryCentral and every
scientist can read your work free of charge
"Open access provides opportunities to our
colleagues in other parts of the globe, by allowing
anyone to view the content free of charge."
W. Jeffery Hurst, The Hershey Company.
- available free of charge to the entire scientific community
- peer reviewed and published immediately upon acceptance
- cited in PubMed and archived on PubMed Central
- yours - you keep the copyright
submit your manuscript here:
http://www.chemistrycentral.com/manuscript/

